\title{
Skiing and its Discontents: Assessing the Turist Experience from a Psychoanalytical, a Neuroscientific and a Sport Philosophical Perspective
}

\author{
Hub Zwart \\ Faculty of Science, Philosophy (ISIS), Radboud University, Nijmegen, The Netherlands
}

\begin{abstract}
This article addresses the question whether skiing as a nature sport enables practitioners to develop a rapport with nature, or rather estranges and insulates them from their mountainous ambiance. To address this question, I analyse a recent skiing movie (Turist, 2014) from a psychoanalytical perspective (skiing as a quest for selfknowledge and as therapy) and from a neuro-scientific perspective (ski resorts as laboratory settings for testing physical and psychic responses to a variety of cues). I conclude that Jean-Paul Sartre's classical but egocentric account of his skiing experiences disavows the technicity involved in contemporary skiing as a sportive practice for the affluent masses, which actually represents an urbanisation of the sublime, symptomatic for the current era (the anthropocene).
\end{abstract}

\section{KEYWORDS}

Philosophy of skiing; sport and cinema; sport and neuroscience; psychoanalysis and cinema; environmental philosophy

\section{Introduction: Skiing and Philosophy}

Skiing as a winter sport unleashes massive annual migrations of individuals, families and peer groups into mountain areas such as the Alps, notwithstanding the obvious drawbacks of this practice, both collectively (the disruptive environmental impact of ski resorts on valuable ecosystems) and individually (expenses involved in skiing, bodily injuries, etc.). Ski resorts endanger alpine ecosystems through continuous construction, enlargement and management of pistes with the help of machine-grading, grooming vehicles and artificial snow (Wipf et al. 2005). They are often established close to nature, in sensitive ecologic zones (Chappelet 2008), so that areas that were formerly deemed inaccessible are now increasingly exploited by the 'skiing industry' (Chivers 1994, 11), resulting in 'urbanisation' of Alpine areas (12).

Let me confess outright that I am a stranger, an outsider to skiing and that I have never participated in this pursuit. I prefer walking and hiking through the mountains, in a Rousseaulike fashion, avoiding ski resorts because from my perspective, whereas walking allows you to develop a rapport with nature, ski resorts rather seem to represent estrangement from the Alpine ambiance, by reducing the Alps (as an archetypically sublime landscape) to mere scenery. Skiing for me exemplifies forgetfulness of nature, to use the Heideggerian term, 
rather than interaction with or openness to nature. A ski resort is definitely a clearing, but not in the Heideggerian sense of the term. Besides the fact that ski resorts entail a devastation of the surrounding landscapes, they seem symptomatic of a commodification of nature, a demise of the sublime: of nature as púбıc: that which emerges, comes forward on its own accord, that which has its own inherent principles of movement and change, that which is simply there without our doing (Aristotle 1980).

At the same time, such outsider assessments should raise suspicion. As I never stood on skies myself, how can I know what skiing really means, or what kind of nature experiences (perhaps unknown to me) are opened-up by it? Moreover, my verdict may stand on the shoulders of a long tradition of philosophical suspicion and resistance against massive sportive entertainment. For although Plato's academy was situated in a sports park (offering gymnastics of the intellect in addition to athletic pursuits such as wrestling, discus throwing and running), authors like Seneca and Cicero already criticised the depraved morality of the public games (circenses) organised in ancient Rome (Sloterdijk 2001, 309), moved by sound philosophical reasoning no doubt (given the outrageous 'bestiality' of the human and animal suffering involved), but in the case of skiing I would like to probe and articulate my discontent with more precision. How to achieve this without becoming actually involved in this questionable practice myself?

It cannot be denied, moreover, that even in the case of skiing, there is a sed contra est, in the form of prominent philosophers who stand out as advocates of this practice. Perhaps the most famous philosophical ski adept was Martin Heidegger. Besides the fact that several pictures of Heidegger on skies can be found on the Internet, it is well known that one of his key concepts, namely Die Kehre, Heidegger's famous'turn', is actually a skiing term, borrowed from the skiing vocabulary, Heidegger's preferred sport (Janicaud 2015, 242). Apparently, he was quite proficient in it, skiing all the way from his famous hut in Todtnauberg to the lecturing hall at the University of Freiburg (Breivik 2011; Moran 2000). The meaning of skiing may have changed dramatically during recent decades, however, so that nowadays skiing not only exemplifies forgetfulness of nature but also the inauthenticity of contemporary consumerist existence, with tourists buying commodified experiences and quality time (Pine and Gilmore 1999) instead of really exposing themselves to authentic ecstatic peak experiences of self-forgetfulness (Martínková 2011; Vannatta 2008).

A very explicit philosophical advocate of skiing was Heidegger's contemporary Jean-Paul Sartre who, in Being and Nothingness (1943), devotes almost a whole chapter to this pursuit. In the winter of 1934-1935, while struggling with his novel Nausea, Simone de Beauvoir persuaded Sartre to go skiing in the Alps near Chamonix together (Martin 2010; Pitt 2013) and Sartre's phenomenological first-person analyses in Being and Nothingness are based on these personal experiences. Sartre discusses skiing in a chapter dealing with doing, having and taking possession, important ingredients of his 'existential psychoanalysis', a phrase which indicates that, whereas Freudian psychoanalysis emphasises the extent to which our selfimage, our whole worldview even, relies on self-deceit, Sartre wants individuals to assume full responsibility for their existence.

Before turning to skiing, Sartre first discusses scientific research as a form of 'appropriation' of nature. Scientific research, according to Sartre, means that certain aspects of the world reveal themselves via me. Nature, Sartre argues, is Diana taking a bath, and the researcher is the hunter who is suddenly and accidentally confronted with her whiteness, her nudity (a dynamics which Sartre refers to as the Acteon complex, 639). The basic desire of science 
is to take possession of this smooth, white body, which remains a hazardous task, but the researcher somehow has to conquer the noema of his desire. Thus, the goal of scientific research is to penetrate and incorporate the object: that which initially appears to me as decidedly not-me.

Besides penetration, there is another form of appropriation, namely contemplation, which is more like caressing and glancing over a surface, and it is here that skiing comes into play (640). Skiing as a sport, Sartre argues, transforms a natural environment into a supporting, enabling element for human action (642), and this explicitly applies to the Alpine slopes used by skiers: the white immensities which, according to Sartre, initially represent pure exteriority, radical spatiality and monotonous indifference: the absolute nudity of substance, the pure apparition of not-me (642), which the skiing subject desires to appropriate and possess. There is something ungraspable about snow, however, for it lacks substance. As soon as we touch it, it disappears, liquefies and evaporates into nothingness. But skiing allows us to own this element. The meaning of skiing resides in the experience of speed and technical ability no doubt, but first and foremost the skier desires to possess these beds of snow. For Sartre, sliding is a form of appropriation, and precisely for that reason, skiing is not a superficial activity. Sliding is a very special mode of appropriation, moreover, enabling a strictly individual relationship with matter. The ideal form of sliding leaves no traces at all, although in reality it always does, so that even Alpine skiing is already less than perfect, because there always is a visible trace, which compromises skiers (hence the disappointment which seizes them when they look behind them and see the imprint which their skis have left on the snow). Caressing a'female' body whose skin we leave intact: that, for Sartre, is the skier's ideal. Through the activity of sliding, the skier affirms his rights over the snow: this is his bed of snow. But appropriation requires a kind of test: it means overcoming a difficulty, a certain resistance, such as: climbing the mountain before descending it, because skiers first have to conquer the smoothness and whiteness before they can appropriate it during the descent. Thus, for Sartre, skiing is a form of appropriation which realises a rapport with Being.

Even if we ignore Sartre's stereotypical depiction of the gender dimension (male subjects conquering, appropriating and owning white, smooth female bodies), his philosophical advocacy of skiing becomes quite problematic in view of the current era of ecological disruption, notably his claim that this act of conquering appropriation may result in establishing a rapport with nature. Would this not rather require an attitude of non-appropriation, of letting nature (letting otherness) be? In view of the massive melting of Arctic ice and the shrinking of the Alpine glaciers, Sartre's depiction of the Alps seems remarkably outdated and (even in the Sartrean sense of the term) irresponsible: a symptom of environmental self-deceit. Overall, Sartre's apologia of skiing reinforces rather than refutes my intuitive assessment. On the positive side, there is (a) the experience of skiing as a form of exploration, an instantiation of our desire to know nature (representing a common ground between practising sports and conducting research); (b) the idea of skiing as a test and (c) skiing as an instantiation of the desire to build a rapport with nature via physical activities, notably the activity of sliding which, ideally, leaves no traces. On the negative side, however, there is first of all the desire to appropriate nature and to transform it into a lusory ambiance. But what renders Sartre's existential psychoanalysis of skiing even more inadequate and unsatisfactory (as a potential contribution to the contemporary philosophical debate on sports and the environment) is his depiction of skiing as a decidedly solitary and individual pursuit. 
What is completely eclipsed in his egocentric portrayal is that skiing requires an infrastructure, a material base: a network of hotels, roads, ski lifts, snow cannons, snow-grooming vehicles and so on. The technicity of skiing, everything which has to be in place in order to transform Alpine nature into a supporting ambiance for the skiing industry, fades into the backdrop, and this makes Sartre's portrayal fairly'superficial'. Doubtlessly, in the 1930s, skiing had not yet evolved into the massive tourist attraction which it has become today, so that in those days it could perhaps still be considered a'nature sport' (whose practitioners interacted with natural features: Krein 2014, 2015), but insofar as skiing during the interbellum really was a solitary, low-tech activity, this reduces the relevance of Sartre's account for the current sport philosophical debate because what used to be marginal and rudimentary perhaps (the technical, infrastructural side of skiing) has now become decidedly visible and dominant. And my negative attitude towards skiing does not concern the physical activity as such of course, but rather everything that comes with it; and precisely this is overlooked in Sartre's self-centred account, which focuses on the experience of sliding.

Thus, Sartre's existential psychoanalysis of skiing results in an aporia, a deadlock. Somehow, I must find another way to put my intuitive verdict (my prejudice?) to the test. According to Breivik (2011,319), we should only speak about sports on the basis of personal experience. Otherwise, we are unable to study aspects that only reveal themselves to those who have reached a sufficient level of mastery. But if practising skiing is out of the question (for environmental reasons), what could count as a convincing substitute? My strategy on such occasions is to revert to genres of the imagination (novels, movies, drama, art, etc.) that open up feasible, in-depth perspectives on practices in which I am not directly involved myself. Several authors have pointed out, moreover, that there is a dramatic side to sport, a resemblance between genres of the imagination and sport activities (Gebauer 1993; Kretchmar 2017; McNamee 2007). In both cases, there is a beginning, a confrontation, a potential rise of tension, a climax (or crisis) and a resolution (Gottschall 2012). Keenan (1973) described sport as a 'tragic form of art' in terms of plot, character development and dramatic structure. More specifically, where movies are concerned, Crosson $(2013,3)$ has suggested that it is no coincidence that modern sport and cinema emerged contemporaneously, towards the end of the nineteenth century. In 1896, when the first Olympic Games were held in Athens, the Lumière Brothers demonstrated their cinématographe in Paris (3). Indeed, cinematic documents, from Olympia (Leni Riefenstahl's classic documentary of the 1936 Berlin Olympics) up to Million Dollar Baby (2004), seem to exemplify this congruency, and in the Internet Movie Database (IMDb) something like 2000 sport movies are now listed.

In order to further explore my intuitions, I opted for a recent Swedish movie named Turist, directed by Ruben Östlund (2014) and translated as Force Majeur, which provides a cinematic window, allowing me to critically reflect on skiing as a sport. In this article, I will use the movie setting provided by Turist as a philosophical laboratory, where various aspects of skiing can be analysed and assessed. In Turist, a ski resort creates an artificial environment where individuals and families (as'research subjects') are exposed to various challenges and circumstances, both mentally and physically, and the question is: How will they respond? This is precisely what we see happening in the movie. The protagonists are confronted with a completely unexpected and threatening (test-like) situation, to which they must react in a split of a second, resulting in self-knowledge. While analysing the movie from multiple perspectives (psychoanalysis, neuroscience and continental philosophy of sport), special attention will be given to the methodological aspects of the use of cinematic documents as 'empirical' input for normative deliberations. 
I will start with a brief resume of the narrative. Subsequently, I will analyse the movie by mutually exposing a psychoanalytical with a neuroscientific perspective, a procedure referred to as triangulation. Finally, I will assess what we have learned about skiing from this case study, and how the dissection of movies may contribute to the philosophy of sport.

\section{Summary}

An apparently happy and affluent Swedish family (the couple Tomas and Ebba, together with their children Vera and Harry) arrives in an expensive ski resort for a five-day ski vacation in the French Alps. The landscape is ostensibly managed, which involves a considerable amount of technicity. Denotations occasionally resound, coming from snow cannons used for avalanche management, interrupting the (usually rather brief) conversations as well as the background music (Vivaldi). The silent white scenery of the gigantic Alps in the distance contrasts with the family's everyday routines (brushing teeth, visiting the toilet, waiting for the lift, checking tablets or iPhones, playing with a drone, eating, drinking, ordering drinks, arguing, sleeping). While having lunch on a terrace with some visitors, a detonation suddenly resounds and an avalanche comes down from above, but father Tomas reassures his children that everything is under control. But as the avalanche comes increasingly close, a general panic ensues. In a split of a second, Tomas grabs his gloves and iPhone and dashes off, leaving his wife and children behind. As the sudden fog gradually disappears, he returns to the terrace, now covered under a film of snowy powder, but it is clear that something has changed. By deserting them, he has shocked and disappointed not only his family members, but also himself. Initially he denies his cowardice, insisting that he did not run away from the table at all, a strategy which infuriates Ebba, who refuses to let it pass. His iPhone has recorded his embarrassing retreat, and when Ebba (during a conversation with Mats and Fanni, a befriended couple) confronts him with the evidence, his resistance collapses. It is now clear that the traumatic scene requires some serious working through on the part of the married couple. Somehow, Tomas's injured self-image must be repaired.

\section{Exposition and Exposure}

How to dissect this cinematic document as a sport philosophical Fallgeschichte? I will approach the movie from two perspectives, resulting in an exercise in philosophical triangulation (Zwart 2016). On the one hand, I will approach the movie from a psychoanalytical perspective, focusing on the experience of trauma (the sudden resurgence of something which seemed forgotten and disavowed) and the therapeutic sessions resulting from this. On the other hand, I will analyse the movie in terms of its experimental design: the movie as a lab-like personality test. In combination, both approaches provide input for a philosophical assessment.

To begin with, a number of dramatic stages can be distinguished in the movie, starting with the 'exposition' stage (Freytag 1863). Via the protagonists, we are introduced to the details of the ambiance: hotel rooms, restaurants, lifts, bedrooms and so on. Nature is visible as scenery, as the scenic backdrop, and the first shots seem to confirm that ski resorts basically entail an obliteration of the sublime. Tourists are not really exposed to or challenged by nature. They see the snow (the white and silent vastness) no doubt, while eating lunch or having a beer, but they do not really seem to experience the phenomenon. The rooms in which they sleep, the cabins that transport them safely to the top, the big machines that 
smoothen the slopes, the fashionable outfit they wear, the food they consume, everything seems perfectly designed to prevent them from any real confrontation with nature. Skiing apparently does not allow them to experience the environment, precisely because it is not at all a'wild place', free from human influence (Dougherty 2007; Zimmermann \& Saura 2017). The artificial scenery rather exemplifies estrangement from nature; they are barred from experiencing the Alpine 'real', to use the Lacanian term. This is the first moment in the dialectical unfolding of events: the control condition. While having their lunch on the terrace, the family members' attitude suggests complete indifference to the astonishing spatiality of the Alps.

But then, suddenly, there is a situation of high intensity, ambiguity and contradiction, a sudden exposure to the disregarded landscape and its looming threats (never completely domesticated): an 'intrusion of the real' (Zwart 2015), the sudden onset of the avalanche, which initially seems under control, but which gradually seems to get out of control, posing a direct threat to the nuclear family's survival. ${ }^{1}$ In Lacanian terms, the real is that which offers resistance to complete 'assimilation' (Lacan 1964/1973, 65), revealing itself as a crevice, a rupture, as something totally unexpected or unacknowledged (Lacan 1960-1961/2001, 58). The real is a disruption which flouts our expectations, something which, from the point of view of everyday behaviour, seemed utterly 'impossible' (Lacan 1971-1972/2011, 141). As Heraclites phrased it many centuries ago: real nature is wont to hide herself and a sudden revelatory experience may prove quite disconcerting or even traumatic (Lacan 1962$1963 / 2004,85$ ff.). In other words, that which seemed contained suddenly comes to the fore, or dys-appears (Leder 1990; Zeiler 2010); although in this case what was absent is not the absent body but rather absent, disregarded nature.

Yet, at the same time this experience seems highly unreal. In accordance with the experimental set-up, this sudden, unexpected, unpredictable and life-threatening event is actually a phantom crisis, subjecting the protagonists to a kind of test: How will they respond? In Turist, skiing is not a contest (neither with others, nor with nature: Kretchmar 1975) but rather a test, and this especially applies to Tomas. The avalanche confronts him with a question: What kind of person (man, father, partner, etc.) are you? That the setting works like a test is confirmed by the multiple discussions that evolve during the remainder of the movie. Mats and Fannie for instance run into a discussion over the issue how Mats himself would have responded. But this question is also taken up by audiences: What would you do? How would you respond?

\section{The Experimental Movie}

Seeing movies as a test-like, experimental design builds on a concept developed by the French novelist Émile Zola (1840-1902), namely the concept of the 'experimental novel', which is here extrapolated to movies. After reading Claude Bernard's famous introduction to experimental medicine (Bernard 1865/1966), Zola (1880/1923) concluded that novels are basically laboratories and that novel-writing means conducting an experiment, by consciously and systematically exposing protagonists (with their personality traits, cultural backgrounds, professions, age, gender, etc.) to experimental stimuli and conditions in order to register and analyse their responses (Conti and Conti 2003; Zwart 2008, 2014). The novelist does not merely describe the world as it presents itself to us, Zola argues, but actively intervenes, confronting literary characters with a number of challenges introduced by the author. 
Thus, novels (but this also applies to movies, I argue) may contribute to our body of knowledge. Indeed, according to Zola, the experimental method puts novel-writing on a scientific footing, so that novels may function as imaginative laboratories, where social phenomena may be systematically analysed. To achieve this, the experimental novel must convey the same sense of detachment and precision as scientific research reports.

A perfect exemplification of the experimental novel, in Zola's sense of the term, is Jack London's The Call of the Wild (1903/1981), which meticulously describes how a dog (named Buck), who grew up in sunny California, is kidnapped and shipped to Alaska to serve as a sledge dog during the Klondike Gold Rush, where he finds himself exposed to completely different conditions: the cold and frost of the Arctic North, the ghostly calm of its white and silent vastness, as London phrases it. He finds himself 'jerked from the heart of civilization and flung into the heart of things primordial' (30), resulting in a 'retrogression' (38), so that his 'civilized self' is gradually erased. Notably, the Californian ethic of love and fairness gives way to the laws of primordial life, the struggle for survival. His civilised canine morality disintegrates and he develops new behavioural repertoires, new habits of sleeping and eating, new senses even. Prolonged exposure to harsh circumstances entails a complete metamorphosis.

If we watch Turist from this perspective, the ski resort (an artificial location in an unfamiliar environment) becomes a laboratory setting. Initially (in contrast to The Call of the Wild), the sheltered, comfortable setting seems like an urban capsule transplanted into a mountainous region. There is something highly artificial about this insulated environment. Ski-lifts, terraces, hotel rooms, restaurants and everything in it seem like laboratory props, brought in by the research team to optimise the ambiance. The avalanche (produced on purpose with the help of snow cannons) becomes a 'stimulus', an experimental condition: a brief exposure to the wild whose call had been submersed. How will the protagonists (the research subjects) cope with this unexpected situation, how will they respond?

The interesting thing is: you cannot know this beforehand. The movie (the avalanche scene) confronts us with something we do not know about ourselves, unless we are willing to expose ourselves to such a situation, to such a test, as naïve subjects preferably, in the experimental sense of the term: subjects who do not know that they are actually being subjected to an experiment. The avalanche is a convincing scene, I would argue, because the situation really seems to work as a plausible personality test.

In fact, such test-like experiments are really being conducted in laboratories across the globe. And the outcome consistently is that if we are confronted with a sudden, seemingly life-threatening stimulus, three types of actions, three behavioural options, may ensue: fight, flight or freeze-a behavioural repertoire we actually share with other mammals. Which of the options will prove to be the most optimal depends on the situation. In the case of a gazelle who suddenly finds itself face-to-face with a hungry lioness, freezing offers the best chance of survival. If such an animal manages to stand completely still, the predator might ignore it. But if you are a passenger on a cruise ship which suddenly capsizes, freezing is by far the worst response imaginable because besides significantly increasing your own risk of drowning, others ('fighters') may feel obliged to try and save you (thereby putting their own lives at risk, for instance by stumbling over other freezers they encounter in corridors, etc.). Flight seems a sensible response in such a situation, unless of course you are the Captain of the ship, of the Costa Concordia for instance, for in that case to desert your ship (while your passengers are still on board) will mean the end of your career and the beginning of 
troublesome legal procedures. But again, the quintessence is that you do not know, unless you have been tested. And it certainly makes sense, on some occasions, to put individuals to a test, to test their 'metal' as it were, before they decide to become a cruise boat Captain, for instance, or a stewardess or a police officer-or before selecting them as marriage partners.

Perhaps this is why some athletes become extremophiles, eager to expose themselves to extreme conditions: they want to put themselves to the test, they want to know something about themselves which otherwise would remain hidden. Dangerous sports put people from relatively safe societies into situations which highlight'human finitude' as a fundamental component of authentic understanding (Martínková \& Jim Parry 2016). Disruption of the everyday life world can provide a glimpse of authenticity (Breivik 2010, 2011). Sartre already underscored the continuity between scientific research (the quest for knowledge) and skiing, and this seems to be confirmed by Turist, although skiing seems directed at deepening self-knowledge rather than nature knowledge. Indeed, outdoor sports may paradoxically learn us more about ourselves than about the environment (Atherton 2007).

\section{Coping with Anxiety: The Socio-Technological World as Behavioural Scaffold}

As indicated, the fight-flight-freeze response is an important topic of research in the contemporary neurosciences, as exemplified for instance by the inaugural lecture of brain scientist/neuropsychologist Karin Roelofs entitled Brain in flight: The anxious brain in action (Roelofs 2012). In 2013, she and her group launched the Neuro-defence research programme, funded by the European Research Council and aimed at investigating freeze-fight-flight reactions in humans by focusing on the neural and endocrine mechanisms underlying these defensive responses (a line of research initiated by Walter Cannon in 1920). In her inaugural lecture, Roelofs refers for instance to the disaster which befell the ferry Estonia during a storm in 1994, an event which caused the death of 852 people, while only 137 passengers and crew members survived. By analysing witness reports, Leach (2004) had already discovered that while some victims (15\%) acted in an efficient and goal-directed manner, the vast majority (70\%) panicked, in other words: they reacted, but not in a very efficient and sensible way. The final 15\% (most of whom drowned) reacted by freezing in the face of danger. They seemed paralysed by the threat, apparently in shock, even when a more active response could have saved them. Such reports raise the question: How would / respond. To find the answer, Roelofs designed a laboratory experiment, involving a'stabilometric force platform' (Roelofs et al. 2010; Roelofs 2017) which exposes subjects to a threatening, a neutral or an affiliative cue, allowing them to test their metal, so that, when things get really rough, their behavioural impulses will not come to them as an (embarrassing?) surprise.

My argument would be that in Turist, the terrace facing the Alps (neutral or even affiliative at first, but threatening all of a sudden) functions as an experimental 'platform', comparable to the stabilometric force platform which Roelofs and her colleagues use to measure spontaneous bodily responses - albeit in an outdoor, less controlled ambiance in the Turist version. The ski resort seems a highly artificial environment, as most of the human-nature interaction is fairly superficial and the protagonists seem isolated from their world rather than interwoven and enmeshed in it. In terms of poise, they seem focused on the horizontal dimension (interpersonal relationships, equipment, meals, etc.) rather than on the vertical dimension: nature and its marvellous summits and distant peaks (Breivik 2011; Todes 2001). 
They do not really seem to experience Alpine grandness and nature does not genuinely seem to speak to them, which makes the terrace a perfect site for a laboratory. The phantom crisis forces the parasympathetic Autonomic Nervous System (ANS)-i.e. that part of the brain which enables a 'rest and digest' physiology — to switch to a fight, flight or freeze response, unleashed by the sympathetic ANS, while switching off the parasympathetic'rest and digest' parts of the system. In Tomas's case, this results in an embarrassing flight response. There is also a link with masculinity, moreover, because someone's tendency to act is a function of testosterone levels, so that administering testosterone may modify the type of response (Roelofs et al. 2010).

In recent decades, neuroscience further elucidated the cellular and molecular mechanisms underlying anxiety, arousal and the fight-flight-freeze response. Besides adrenaline, noradrenaline and steroid cortisol, the protein stathmin, encoded by the stathmin gene (STMN1), plays a crucial role. Stathmin knockout mice are significantly less sensitive to fear (both innate and learned) and show less anxiety when exposed to new and potentially dangerous situations (Brocke et al. 2010; Martel et al. 2008). Top athletes from the mythic past like Siegfried (who knew no fear) may now be seen as cases of stathmin deficiency, causing the Siegfried complex as it were, as the STMN1 genotype has functional relevance for the acquisition and expression of basic fear and anxiety responses also in humans (Brocke et al. 2010). Brain research has entered sport science as well, as exemplified by a recent book entitled The Athletic Brain: How Neuroscience is Revolutionising Sport and Can Help You Perform Better by Amit Katwala (2016), focusing on the plasticity of the brain, however: on the brain's ability to learn and on the ways in which sport changes your brain. The athletic brain is a trained brain as sporting skills become automated, so that athletes who are 'in the zone' experience a state of flow (optimal relaxed arousal).

Genealogically speaking, this type of research descends from the work of Ivan Pavlov (a key source of inspiration for Walter Cannon as well, Smith 2008) and his famous distinction between conditioned and unconditioned reflexes. Whereas unconditioned fear may be seen as an evolutionary relic, the hard-wired fright response can be subdued by learning: by establishing conditioned responses, for instance by habituating skiers to experiences such as speedily sliding down a slope or facing snowy white expanses. Conditioning may be seen as a form of compensation, psychoanalytically speaking. The primordial experience of anxiety (invoked by mountainous landscapes) is mitigated.

But neuroscientific research may easily slide into neuro-centrism, i.e. the idea that we, instead of being mundane and worldly beings (embedded in socio-cultural environments), basically are our brain. The avalanche experience in Turist is an antidote against this tendency. In normal, everyday situations, Tomas has learned to compensate and conceal his susceptibility to the flight response. But the avalanche reveals the extent to which his casualness actually depends on the socio-technical ambiance. When the reliable world suddenly and momentarily collapses, the conditioned responses become disrupted and the primordial response takes over. The avalanche is reminiscent, I would argue, of the famous disruptive event which struck Pavlov's laboratory on 22 September 1924 when, during a flooding of the river Neva, his conditioned dogs were forced to swim to the top of their cells to avoid drowning, until one of the laboratory assistants finally came to their rescue. As a consequence, in a significant number of dogs, the carefully established conditioned reflexes were completely deranged (Pavlov 1951). Their normal environment had worked as a scaffold supporting their learned behaviour, but now they were thrown back on their resurging, 
primordial, unconditional reflexes. Laboratories are artificial worlds designed to keep the chaotic complexities of the outside world at bay, and the flooding of the River Neva was an intrusion of the Real.

\section{Therapy, Denouement and Working Through}

The remainder of the movie is basically a painful dissection of Tomas's personality, revolving around his fatal mistake, his ámaptía in the Aristotelian sense of the term (Aristotle 1982). It was a mistake, a Fehlleistung no doubt, but as Freud argued (1917/1940) it is via our mistakes (rather than via our athletic achievements, e.g. Tomas' technical ability to slide smoothly across the slopes) that we really get to know ourselves.

My thesis is that Tomas and Ebba, unconsciously perhaps, asked themselves the very question that is triggered by the movie: How will I respond? Tourism is a present-day version of a pilgrimage to the Temple of Apollo at Delphi in ancient Greece, undertaken with the objective of knowing yourself, as indicated by the famous adage written on the sanctuary's

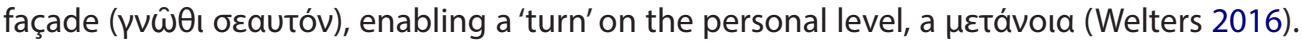
Skiing in the Alps provides a lusory alternative to going on a pilgrimage or paying a visit to the neuro-defence laboratory, but on all three occasions, the motivating question is basically the same. The lunch on the terrace constitutes a quasi-experimental situation, exposing the family members to a threatening cue, with no real physical danger involved: a phantom crisis. They are subjected (semi-voluntarily) to a personality test. Question: Can your (can his?) instincts be trusted?

Tomas unfortunately fails the test. His response seems to give something away about himself which he apparently did not know himself. His own life, his iPhone even, has more value to him than the family he is supposed to protect. Psychoanalytically speaking, his role as father figure is based on self-deceit and his Fehlleistung betrays him, resulting in an embarrassing, yet ambiguous situation. For yes, he failed, in a normative sense of the term, but at the same time he is not responsible for his action because, from a neuroscientific perspective, it was his brain system which unleashed the unconditional response. His body reacted like a cybernetic machine. Remember that it all happened in a flash of a second. Tomas himself is a witness of his own behaviour. He reacts to his reaction in retrospect, but neuroscientifically speaking he was unable to prevent it. It was his amygdala, so to speak, sending brainwaves to brainstem and striatum, several milliseconds before his frontal neocortex realised what he was doing. Faced with an unexpected threat, he proved unable to inhibit his 'automatic action tendencies' so as to 'optimize adequate response capacity' (Roelofs 2017), but this is because, neuroscientifically speaking, emotional brain activity ('hot cognition') is able to process information in no time (within 20 ms or so), therefore responding much faster than rational brain systems ('cold cognition').

His initial response to Ebba's comments and questions is denial. Tomas self-edits his memories and flatly refutes the accusation, which infuriates Ebba even more. But post-modern existence creates panoptic situations because we are always being seen. Our behaviour is continuously recorded, as also happens under laboratory conditions (all the world's a laboratory nowadays). We are permanently under the gaze of the other, via self-tracking devices such as Tomas's iPhone, switched on to videotape the phantom avalanche. The very item he valued so much in the turmoil gives him away. 
When Ebba presses Tomas to explain himself in front of the befriended couple, Mats supports his friend via 'rationalisation.' Maybe it had been a Darwinian response: get away immediately, so that you will be able dig out and safe your family members later. This interpretation seems implausible and does not really help. Working through and acting out seem the only options. And indeed, several therapeutic sessions emerge during the remainder of the movie (the avalanche already occurs on day two of their visit). At a certain point, Ebba confronts Tomas in the corridor. He cries and confesses how he hates himself, and she drags him back into their suite where he collapses, so that his children come to hug their sobbing father, urging Ebba to join the therapeutic hug.

Friend Mats tries another option by taking him off piste to a spot where they really seem to experience the immense snowy surroundings for the first time. Here, Mats advises Tomas to scream. Apparently, he had been in scream therapy himself and it had worked. And indeed, Tomas's scream echoes across the Alps. It is as if a rapport, a dialogue with nature is now established after all. Back in the resort, he is overrun by a large group of young naked males who seem to enjoy a collective, intimidating scream ritual.

But these sessions cannot eradicate the fact that all the family members (Ebba, their children, but also Tomas himself) now look at him with different eyes. Tomas's response to the threat entails a narcissistic offence. His self-image is damaged (a psychic variant of the physical damage which skiing so often has in stall for tourists). The disruptive experience also involves a gender dimension. Whereas Ebba 'instinctively' tries to save her children, Tomas's masculinity fails him and the collapse of his male identity is presented as an emasculated experience, psychoanalytically speaking.

Most of the working though entails sessions of the talking cure type, reminiscent of another Swedish movie: Ingmar Bergman's Scenes from a Marriage (1973). In the Nordic tradition of Ibsen, what has been experienced must be talked through, and other characters are dragged into the verbalisation of their marriage crisis. The objective is reparation and individuation. The traumatic disclosure must be embedded in Tomas's self-narrative again.

\section{Philosophical Reflections: Triangulation}

What does this cinematic case study contribute to the philosophy of skiing? From an existentialist perspective, Turist reveals how ski resorts as infrastructures transform a natural environment into an ambiance for lusory activity. What seems absent in Sartre's portrayal is quite ostensibly brought to the fore: Alpine nature framed as a Gestell, to use the Heideggerian term, so that the threatening naturalness and otherness of nature seems significantly subdued. The protagonists become trapped in an inauthentic situation, into which they have 'fallen' in the Heideggerian sense. Quite unexpectedly, due to the approach of the avalanche, which seems to get out of control, this protective technological screen is temporarily lifted or suspended, so that the family members suddenly find themselves face-to-face with the threatening real. This experience reveals that, contrary to Sartre's claim, the sense of mastery entailed in the experience of sliding over a slope is illusory. For all the technicity involved, nature is still there, and the skiers never really conquer it. In Sartre's own terms, his account represents an egocentric instance of self-deceit, resulting from a failure to acknowledge the level of technicity (environmental disruption) that is required, especially today, in the era of mass tourism, to facilitate the sliding experience described by Sartre: the experience of skiers that they allegedly master and own the Alpine slopes simply by sliding over them. In Turist, 
shots of people sliding downwards are actually quite rare, as most of the movie is devoted to a plethora of other activities entailed in visiting ski resorts. But the confrontation with the avalanche disrupts this self-deceit. It reveals the vulnerability of human beings (now momentarily thrown back onto their primal impulses, their body wisdom), but also the vulnerability of nature because there is something drastically artificial about these carefully managed avalanches, including the one that seemingly gets out of control. Even the phantom crisis ends as a melting film of harmless, snowy powder: something bereft of substance.

As a cinematic Fallgeschichte, we analysed Turist from multiple perspectives: philosophical 'triangulation' (Zwart 2016). The movie was approached from a Sartrean (existential psychoanalytical), a Lacanian (psychoanalytical) and a neuroscientific perspective (building on the concept of the experimental movie). Although Turist is not really an experiment (the terrace is not as abundantly equipped with technical contrivances as the Radboud stabilometric force platform for instance), its narrative structure nonetheless reflects an experimental design. This combined reading of the cinematic narrative (in terms of a psychoanalytic assessment and a neuroscientific test) allows us to discern the 'morale' of the story, its relevance for contemporary debates in sport philosophy.

The most important sport philosophical issue for me is the question whether skiing enables or prevents practitioners from establishing a genuine rapport with nature (the natural environment, the Alpine landscape). Will nature sports like skiing contribute to ecological disruption, or rather to an ecocentric turn, so that skiing may become nature-friendly and eco-compatible again? My (provisional) conclusion (based on a single cinematic document, $N=1$ ) is that Turist emphasises what is obscured in Sartre's analysis, namely that the technicity of skiing (as a collective practice) reduces nature to scenery, a mere condition for lusory human activity (in accordance with Heidegger's concept of the appropriation, exploitation and framing of nature as a standing reserve, a Gestell). Sartre's existential psychoanalytical interpretation underscores that skiing is basically an egocentric practice which, rather than establishing a genuine rapport with nature, produces an illusory experience of mastery over nature (an illusion which is effectively demolished by the avalanche experience). In other words, the experience of conquering nature (by sliding gently across snowy slopes) is based on self-deceit. Alpine nature is conquered, not by the sliding individual, but by technological infrastructures: the framing of Alpine nature as an ambiance for human lusory activity.

But Alpine nature is never completely owned or conquered, and the mock avalanche is, philosophically speaking, a therapeutic event which allows us to rectify this deceptive view (framing ourselves as omnipotent beings while we actually remain fundamentally vulnerable and dependent on technology). Tomas's response (initially disavowing the threat, claiming that everything is under control, but subsequently opting for a flight response, indicating that, unconsciously perhaps, the awareness that nature is not completely conquered or controlled is still very much alive) is symptomatic of this attitude towards nature. Perhaps his scream therapy can be regarded as an effort to reach out to nature and to atone for his thoughtlessness after all. But overall, the skiing industry as represented in Turist exemplifies the experience economy (Pine and Gilmore 1999), fabricating commodified events for customers, so that experiences become commodities (tourists as consumers of 'quality time'). Such fabricated experiences bar us from a genuine nature experience, rather than opening us up to it, so that skiing is not really a'nature sport' (Krein, 2014, 2015).

Ebba's and Tomas's decision to travel to the Alps is not motivated by a desire to build a rapport with nature, but rather by ego-centric motives. They want to know themselves and 
each other, unconsciously perhaps, by addressing the question how they will respond to the social, psychic and physical challenges involved in such a pursuit. In other words, although there is continuity between research and skiing (as Sartre indicated), the noema of their quest is not a natural object, but rather their own persona, their own personal Self. Etymologically speaking, the term persona means mask, and the avalanche suddenly removes the mask of

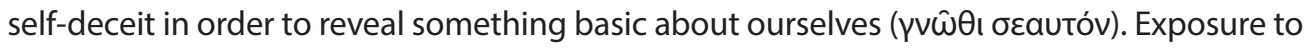
hazards results in self-exposure. Skiing is an egocentric rather than an eco-centric practice. Besides certain levels of enjoyment (in combination with frustration, irritation, injuries, and the like), it involves test-like experiences (personality tests), triggering self-reflection. From a neuroscientific perspective, the movie emphasises the inadequacy of the neuro-centric conviction that we are our brain. Turist reveals the extent to which conditioned responses continue to rely on the socio-technological environment as a scaffold. As soon as this world collapses (due to a phantom crisis), research subjects are thrown back on their unconditional responses.

Is skiing an 'urban' outdoors sport (performed on artificial lawns or constructed grounds, deliberately made smoother, squarer, colder, etc.) or rather a 'remote' sport (performed in natural environments, characterised by self-propelled activity and limited infrastructures, taking what is there as playing field) as described by Howe (2008)? It is something which hovers in between. In the Turist experience, gliding amidst snowy vistas is intimately entangled with technological forms of transport, motorised vehicles, ski-lifts, groomed slopes and artificial snow. Skiing 'artificialises' and urbanises nature (Howe 2008, 3), and although (as Howe phrases it) such semi-urbanised, pseudo-remote activities inevitably'lose their potential to develop self-understanding and personal growth by offering various kinds of tests' (2), Turist indicates that test-like situations may nonetheless unexpectedly resurge.

This leads to a differential diagnostics. On the negative side, there is a tendency in skiing (even in Sartre as a philosopher-skier) to disavow the ecological and technological dimensions of skiing, so that the nature experiences evoked by this practice are much less natural than they purport to be, while environmental awareness is silenced rather than promoted. Skiing as a sportive practice for the affluent masses represents an urbanisation of the sublime, symptomatic for the current era: the anthropocene (Lemmens and Hui 2016). On the positive side, the basic objective of skiing is self-knowledge: putting yourself and others to the test in a carefully designed environment in order to realise to what extent our reflexes and personality traits depend on our supportive world rather than on our brain, followed by therapeutic sessions. Turist is basically a 'morality play' (McNamee 2007) and skiing cinema a moral education tool.

\section{Note}

1. A fragment of the scene is available on the Internet: https://www.youtube.com/ watch?v=unbEUpLkIcl

\section{Acknowledgement}

This article is based on a lecture presented and discussed at the 2017 BPSA/EAPS Conference at Radboud University Nijmegen, The Netherlands, April 252017.

\section{Disclosure Statement}

No potential conflict of interest was reported by the author. 


\section{ORCID}

Hub Zwart (iD http://orcid.org/0000-0001-8846-5213

\section{References}

ARISTOTLE. 1980. Physics (Aristotle 4). The Loeb classical library. Cambridge: Harvard University Press. London: Heinemann.

ARISTOTLE. 1982. Art of Rhetoric (Aristotle 22). The Loeb classical library. Cambridge: Harvard University Press. London: Heinemann.

ATHERTON, JOHN. 2007. Philosophy outdoors: First person physical. In Philosophy, risk and adventure sports, edited by Michael McNamee. London: Routledge: 43-55.

BERNARD, CLAUDE. 1865/1966. Introduction à l'étude de la médecine expérimentale [Introduction to the study of experimental medicine]. Paris: Garnier-Flammarion.

BREIVIK, GUNNAR. 2010. Being-in-the-void: A Heideggerian analysis of skydiving. Journal of the Philosophy of Sport 37 (1): 29-46.

BREIVIK, GUNNAR. 2011. Dangerous play with the elements: Towards a phenomenology of risk sports. Sport, Ethics and Philosophy 5 (3): 314-30.

BROCKE, BURKHARD, KLAUS-PETER LESCH, DIANA ARMBRUSTER, DIRK A. MOSER, ANETT MÜLLER, ALEXANDER STROBEL, and CLEMENS KIRSCHBAUM. 2010. Stathmin, a gene regulating neural plasticity, affects fear and anxiety processing in humans. American Journal of Medical Genetics B: Neuropsychiatric Genetics 153B (1): 243-51. doi:10.1002/ajmg.b.30989.

CANNON, WALTER. 1920. Bodily changes in pain, hunger, fear and rage. New York, NY: Appleton.

CHAPPELET, JEAN-LOUP. 2008. Olympic environmental concerns as a legacy of the winter games. International Journal of the History of Sport 25 (14): 1884-1902. doi:10.1080/09523360802438991.

CHIVERS, JOHN. 1994. Effect of the skiing industry on the environment. Conventry: School of International Studies and Law.

CONTI, FIORENZO, and SILVANA IRRERA CONTI. 2003. On science and literature: A lesson from the Bernard-Zola case. Biology in History 53 (9): 865-869.

CROSSON, SEÁN. 2013. Sport and film. London: Routledge.

DOUGHERTY, A.P. 2007. Aesthetic and ethical issues concerning sport in wilder places. In Philosophy, risk and adventure sports, edited by Michael McNamee. London: Routledge: 94-105.

FREUD, SIGMUND. 1917/1940. Vorlesungen zur Einführung in die Psychoanalyse [Introductory Lectures on

Psychoanalysis]. Gesammelte Werkte XI. London: Imago.

FREYTAG, GUSTAV. 1863. Die Technik des Dramas [Technique of the Drama]. Leipzig: Hirzel.

GEBAUER, GUNTHER. 1993. Sport, theatre, and ritual: Three ways of world-making. Journal of the Philosophy of Sport 20: 102-106.

GOTTSCHALL, JONATHAN. 2012. The storytelling animal: How stories make us human. New York, NY: Houghton Mifflin Harcourt.

HOWE, LESLIE A. 2008. Remote sport: Risk and self-knowledge in wilder spaces. Journal of the Philosophy of Sport 35 (1): 1-16. doi:10.1080/00948705.2008.9714724.

JANICAUD, DOMINIQUE. 2015. Heidegger in France. Bloomington: Indiana University Press.

KATWALA, AMIT. 2016. The Athletic brain: How neuroscience is revolutionising sport and can help you perform better. New York, NY: Simon and Schuster.

KEENAN, FRANCIS. 1973. The athletic contest as a 'tragic' form of art. In The philosophy of sport: A collection of original essays, edited by Robert Osterhoudt. Springfield, MA: Thomas: 309-326.

KREIN, KEVIN. 2014. Nature sports. Journal of the Philosophy of Sport 41 (2): 193-208. doi:10.1080/00948 705.2013.785417.

KREIN, KEVIN. 2015. Reflections on competition and nature sports. Sport, Ethics and Philosophy 9 (3): 271-286.

KRETCHMAR, SCOTT. 1975. From test to contest: An analysis of two kinds of counterpoint in sport. Journal of the Philosophy of Sport 2: 23-30.

KRETCHMAR, SCOTT. 2017. Games and fiction: Partners in the evolution of culture. Sport, Ethics and Philosophy 11 (1): 12-25. doi:10.1080/17511321.2017.1294554. 
LACAN, JACQUES. 1960-1961/2001. Le Séminaire VIII: Le transfert [Seminar VIII: Transference]. Paris: Éditions du Seuil.

LACAN, JACQUES. 1962-1963/2004. Le Séminaire Livre X: L'Angoisse [Seminar X: Anxiety]. Paris: Éditions du Seuil.

LACAN, JACQUES. 1964/1973. Le Séminaire XI: Les quatre concepts fondamentaux de la psychanalyse [Seminar XI:The four fundamental concepts of psychoanalysis]. Paris: Éditions du Seuil.

LACAN, JACQUES. 1971-1972/2011. Le Séminaire XIX: ... Ou pire [Seminar XIX: ...Or Worse]. Paris: Éditions du Seuil.

LEACH, JOHN. 2004. Why people 'freeze' in an emergency: Temporal and cognitive constraints on survival responses. Aviation, Space, and Environmental Medicine 75 (6): 539-542.

LEDER, DREW. 1990. The absent body. Chicago: The University of Chicago Press.

LEMMENS, PIETER, and YUK HUI. 2016. Apocalypse now! Peter Sloterdijk and Bernard Stiegler on the anthropocene. Boundary 2. www.boundary2.org.

LONDON, JACK. 1903/1981. The call of the Wild/White Fang. Toronto etc.: Bantam Books.

MARTEL, G., A. NISHI, and G.P. SHUMYATSKY. 2008, September. Stathmin reveals dissociable roles of the basolateral amygdala in parental and social behaviours. Proceedings of the National academy of Sciences of the United States of America 105 (38): 14620-14625. doi:10.1073/pnas.0807507105.

MARTIN, ANDY. 2010. Swimming and skiing: Two modes of existential consciousness. Sport, Ethics and Philosophy 4 (1): 42-51. doi:10.1080/17511320903264206.

MARTínKOVÁ, IRENA. 2011. Anthropos as kinanthropos: Heidegger and Patočka on human movement. Sport, Ethics and Philosophy 5 (3): 217-230. doi:10.1080/17511321.2011.602573.

MARTíNKOVÁ, IRENA, and JIM PARRY. 2016. Heideggerian hermeneutics and its application to sport. Sport, Ethics and Philosophy 10 (4): 364-374. doi:10.1080/17511321.2016.1261365.

MCNAMEE, MICHAEL. 2007. Sports, virtues and vices: Morality plays. London, New York: Routledge.

MORAN, DERMOT. 2000. Introduction to phenomenology. London, New York: Routledge.

ÖSTLUND, RUBEN. 2014. Force Majeure/Turist. Beofilm et al.

PAVLOV, IVAN. 1951. Relations between excitation and inhibitions: experimental neurosis in dogs. Works III (2): 25-50. Moscow: Progress.

PINE, JOSEPH, and JAMES GILMORE. 1999. The experience economy. Boston, MA: Harvard Business School Press. PITT, REBECCA. 2013. Play and being in Jean-Paul Sartre's being and nothingness. In The philosophy of play, edited by Emily Ryall, Wendy Russell and Malcolm MacLean. Abingdon: Routledge: 109-119. ROELOFS, KARIN. 2012. Hersenen op de vlucht: het angstige brein in actie [Brain in flight: The anxious brain in action]. Nijmegen: Radboud University.

ROELOFS, KARIN. 2017. Freeze for action: Neurobiological mechanisms in animal and human freezing.

Philosophical Transactions of the Royal Society B 372: 20160206. doi:10.1098/rstb.2016.0206.

ROELOFS, KARIN, MURIEL HAGENAARS, and JOHN STINS. 2010. Facing freeze: Social threat induces bodily freeze

in humans. Psychological Science 21 (11): 1575-1581.

SARTRE, JEAN-PAUL. 1943. L'être et le néant. Essai d'ontologie phénoménologique [Being and Nothingness:

An Essay on Phenomenological Ontology]. Paris: Gallimard.

SLOTERDIJK, PETER. 2001. Nicht gerettet. Versuche nach Heidegger. Frankfurt: Suhrkamp.

SMITH, G.P. 2008. Unacknowledged contributions of Pavlov and Barcroft to Cannon's theory of homeostasis.

Appetite 51 (3): 428-32. doi:10.1016/j.appet.2008.07.003.

TODES, SAMUEL. 2001. Body and world. Cambridge, MA, London: The MIT Press.

VANNATTA, SETH. 2008. A phenomenology of sport: Playing and passive synthesis. Journal of the Philosophy of Sport 35 (1): 63-72.

WELTERS, RON. 2016. On ascetic practices and hermeneutical cycles. Sport, Ethics and Philosophy 10 (4): 430-443. doi:10.1080/17511321.2016.1201526.

WIPF, SONJA, CHRISTIAEN RIXEN, MARKUS FISCHER, BERNARD SCHMIDT, and VERONIKA STOECKLY. 2005. Effects of ski piste preparation on alpine vegetation. Journal of Applied Ecology 42 (2): 306-316.

ZEILER, KRISTIN. 2010. A phenomenological analysis of bodily self-awareness in the experience of pain and pleasure: On dys-appearance and eu-appearance. Medicine, Health Care and Philosophy 13: 333-342. doi:10.1007/s11019-010-9237-4.

ZIMMERMANN, ANA, and SORAIA SAURA. 2017. Body, environment and adventure: Experience and spatiality. Sport, Ethics and Philosophy 11 (2): 155-168. doi:10.1080/17511321.2016.1210207. 
ZOLA, ÉMILE. 1880/1923. Le roman expérimental. Paris: Charpentier.

ZWART, HUB. 2008. Understanding nature: Case studies in comparative epistemology. Dordrecht: Springer. ZWART, HUB. 2014. Limitless as a neuro-pharmaceutical experiment and as a Daseinsanalyse: On the use of fiction in preparatory debates on cognitive enhancement. Medicine, Health Care \& Philosophy: A European Journal 17 (1): 29-38.

ZWART, HUB. 2015. The call from afar: A Heideggerian-Lacanian rereading of Ibsen's The Lady from the Sea (published online). Ibsen Studies 15 (2): 172-202. doi:10.1080/15021866.2015.1117854.

ZWART, HUB. 2016. Laboratory alice: A Lacanian Rereading of Lewis Carroll?s Alice-Stories as anticipatory reflections on experimental psychology and neuroscience. American Imago 73 (3): 275-305. 